\title{
Integração Econômica e Comercial entre Peru e Brasil a partir do Ano 2000
}

\author{
Economic Integration and Trade between \\ Peru and Brazil from the Year 2000
}

Miriam Glenda Anyosa Chuchon(*)

\begin{abstract}
Resumo: Este artigo tem por objetivo identificar as diferenças e semelhanças do intercâmbio comercial de produtos e serviços entre Peru e Brasil analisando a evolução das relações bilaterais no período de 2000 a 2008. Para isso, o trabalho foi dividido em duas partes: a primeira mostra os perfis econômicos nacionais nas relações bilaterais e a segunda reflete sobre as questões do comércio exterior entre ambos os países. Constatou-se a necessidade de eliminar divergências nos dados estatísticos disponibilizados sobre o comércio bilateral pelas instituições brasileiras e aqueles advindos de órgãos peruanos ligados ao assunto. Também foi verificada a falta de harmonização na qualificação dos produtos tornando-se necessário minimizá-las, sejam elas normativas e/ou reguladoras. A pesquisa envolveu levantamentos bibliográficos e bibliográfico-digitais, além de análise exaustiva das informações disponíveis aplicáveis a cada situação peculiar.
\end{abstract}

Palavras-chave: Acordos de Livre Comércio; Integração; Complementaridade; Bilateralismo.

Summary: This article aims to identify the differences and similarities of the commercial exchange of products and services between Peru and Brazil by analyzing the development of bilateral relations in the period 2000 to 2008 . For this reason, the work was divided into two parts: the first shows the national economic profiles in the bilateral relations and the second reflects on the issues of foreign trade between both countries. It was found that the necessity of to eliminate the differences in the statistical data available on bilateral trade by Brazilian institutions and those deriving from Peruvians organs linked to the subject. It was also verified the lack of harmonisation in the skills of the products become necessary to minimize them, whether they are normative and/or regulators. The research involved surveys in literature and bibliographic-digital, in addition to exhaustive analysis of available information applicable to each particular situation.

Key Words: Free-Trade Agreements; Integration; Complementarities; Bilateralism.

(*) Mestre em Ciências pelo Prog rama de Pós-Graduação Interunidades em Integração da América Latina - Prolam/USP - Prolam/USP. E-mail:<miriamglenda@yahoo.com.br>. Recebido em 11.3.2010 e aceito em 13.10.2011. 


\section{INTRODUÇÃO}

Este artigo pretende identificar convergências e divergências nas relações comerciais entre Peru e Brasil a partir do ano 2000 objetivando distinguir os benefícios e as oportunidades decorrentes da "integração comercial", ignorada no passado, mas alterada paulatinamente ao longo da última década. É necessário ressaltar que, no caso, o maior crescimento das transações bilaterais certamente poderá ser impulsionado caso sejam adotadas estratégias, ações de complementaridade e políticas específicas por ambas as partes.

Após traçar os perfis econômicos nacionais das relações bilaterais, uma reflexão sobre o comércio exterior entre o Brasil e o Peru servirá de apoio na tentativa de responder ao questionamento quanto à possibilidade de um acordo de negócios entre essas nações latino -americanas vizinhas propiciar uma integração efetiva entre ambas e contribuir para fomentar uma maior integração econômica regional sem regulamentações interestatais. Esta certamente pode aflorar, a exemplo do que já aconteceu em outras partes do mundo, sem envolver necessariamente integração política e a "formação de blocos".

A pesquisa envolveu levantamentos bibliográficos e outros de natureza bibliográfico-digitais, além de análise exaustiva das informações disponíveis aplicáveis a cada situação peculiar. A abordagem dos dados do comércio exterior entre Brasil e Peru compreendeu a compatibilização dos informes estatísticos de ambas as partes e a averiguação de divergências ou não — sejam normativas ou reguladoras — na qualificação dos produtos. Estas, caso aconteçam, certamente deverão ser objeto de medidas próprias a fim de serem minimizadas ou eliminadas.

\section{Relações Bilaterais Comerciais entre Peru e Brasil}

Antecedentes - Ao longo da história, as relações entre Peru e Brasil foram pouco significativas; na agenda bilateral peruana/brasileira, foi dada prioridade à solução das questões limítrofes carecendo de conteúdo econômico-comercial. Segundo Costa (1987, p. 44), mesmo depois da solução apressada que se deu às diferenças limítrofes e acordos com ausência de enfrentamentos bélicos na subscrição do Tratado de Rio Branco em 1909, o Peru sempre teve receio das futuras e potenciais aspirações expansionistas do Brasil, pela insistência que demonstrou em utilizar o princípio do uti possidetis facto na solução das disputas territoriais e sua política de assentamentos bandeirantes em amplos setores da Amazônia.

Esta insegurança que o Peru tinha na época foi resultado também da estratégia que o Brasil usou no final da década de cinquenta para ocupar seus territórios amazônicos. Segundo Mercado Jarrin (1986), a ocupação do Planalto Central onde está o divortium aquarium das três maiores bacias hidrográficas brasileiras — Prata, Amazonas e São Francisco - , só se conseguiria mediante um plano de integração vial (meio de transporte) do litoral atlântico unindo o polo industrial dos estados do sul (Paraná, Santa Catarina, e Rio Grande do Sul) com os principais centros urbanos do nordeste. Este plano seria complementado com cinco projetos de grande relevância: a) a mudança da capital do país para Brasília (1960) e sua união por estrada com a cidade de Belém; b) a construção da rodovia Transamazônica paralela ao sul do rio Amazonas em direção leste-oeste, desde recife no 
Atlântico até Cruzeiro do Sul, muito perto da fronteira com Peru; c) o projeto da rodovia Periférica do Norte, que percorreria as fronteiras das Guianas, Venezuela, Colômbia e o nordeste de Peru; d) o ressurgimento de Manaus como zona franca; e) o projeto SUDAM/ RADAM para desenvolver projetos agropecuários na Amazônia. Destes, só a estrada Periférica do Norte não se concretizou com êxito.

A ocupação da Amazônia teve várias implicações para os países limítrofes, segundo Costa (1984, p. 14), sendo estas as consideradas mais relevantes: a) facilitou-se a presença de empresas e capitais estrangeiros na região, pela própria falta de recursos próprios do governo brasileiro, criando problemas de segurança nacional com o governo militar peruano; b) pelo interesse de diferentes grupos do meio ambiente em defender dos possíveis efeitos nocivos que a crescente exploração da Amazônia ocasionaria em longo prazo, como a depredação e o recuo de comunidades nativas entre outros; c) a ênfase de desenvolvimento imposto pelo Brasil na região fez ressurgir o chamado fantasma do "expansionismo brasileiro" e as suspeitas de uma eventual militarização da Amazônia, sendo este o motivo principal para modelar a política geoestratégica peruana em relação ao Brasil nas décadas de 1960 e 1970 do Século XX.

Retomada dos Acordos Comerciais Bilaterais - Um mês depois do golpe militar de Morales Bermúdez, em novembro de 1975, o Chanceler brasileiro Azevedo da Silveira foi a Lima para discutir uma nova agenda com três pontos-chaves: a) a possibilidade de um acordo bilateral; b) o interesse do Brasil na exploração de metais e minerais não ferrosos peruanos; c) a promoção da cooperação científica e tecnológica, especialmente no âmbito nuclear, como indica Costa (1987, p. 49-51). Mais uma vez, na reunião da cúpula presidencial peruana-brasileira em cinco de novembro de 1976, como resultado dos trabalhos anteriores, o tema de cooperação bilateral que maior ênfase teve foi a cooperação amazônica. Mesmo assim esta reunião de Morales Bermúdez-Geisel marcou o fim de um período de isolamento político para ambos os países.

Durante os anos seguintes, houve tentativas de programar ações conjuntas com o intuito de avançar na cooperação econômica e física regional que permitissem fortalecer a democracia e enfrentar a proliferação das ameaças de caráter transnacional. Assim, a partir da visita do presidente Fernando Henrique Cardoso ao Peru em 1999, como afirma Samanez Bendezu (2001, p. 12-14), se assinou o chamado "Plano de Ação de Lima" que estabeleceu sete grupos de trabalho: 1. Amazônia e Fronteira Comum; 2.Integração Física e Transportes; 3. Meio Ambiente; 4. Narcotráfico; 5. Cooperação Técnica; 6. Promoção Econômica e Comercial; e 7. Relações Culturais.

A retomada da relação bilateral que Fernando Henrique Cardoso propôs está baseada no critério geográfico que vincula complicadamente, ou melhor, desvincula ambos os países. Foi este o entendimento que levou o Itamaraty a convocar em Brasília para a primeira "Cúpula Sul-americana" (Cumbre Sudamericana) em 31 de agosto/o 1 de setembro de 2000. Nela, a discussão girou em torno do aproveitamento da geografia e dos recursos naturais, assim como a promoção da integração física dos espaços como um próximo sinônimo de crescimento econômico da sub-região.

Depois da primeira Cúpula Sul-americana, o Ministro das Relações Exteriores do Peru, Diego García Sayan, visitou o Brasil oficialmente em junho de 2001, com a finalidade 
de fortalecer as relações bilaterais. Como primeiro resultado, o governo de transição do Presidente Valentin Paniagua concordou em estabelecer um "Mecanismo Bilateral de Consulta e Coordenação Política ao nível de Ministros das Relações Exteriores" entre ambos os países. Este mecanismo substituiu o existente até aquele momento. Cabe ressaltar que, durante a reunião de García Sayán e Celso Lafer, também foi relevante a discussão sobre a integração física dentro dos moldes da "Iniciativa para a Integração da Infraestrutura Regional da América do Sul” (IIRSA) — criada pela Primeira Cúpula Presidencial Sul-americana. Para Samanez Bendezu (2001, p. 18), a partir das declarações formuladas durante o encontro dos Chanceleres em Brasília, pode-se deduzir que os governos do Peru e do Brasil consideram a integração física como o meio sine qua non para o incremento do escasso intercâmbio comercial bilateral. Constitui, portanto, um novo começo crucial por vincular explicitamente, pela primeira vez na história das relações bilaterais, os temas de integração física e comércio, que sempre foram considerados separadamente na Agenda Peruana-brasileira desde os inícios da década de 1970.

As reuniões dos presidentes Alejandro Toledo de Peru e Luis Ignácio Lula da Silva, ocorridas nos dias 24 e 25 de agosto de 2003, representam a culminância dos esforços diplomáticos de ambos os governos em estabelecer uma nova ligação estratégica que sirva de base para o projeto de um possível espaço geográfico amplo e integrado na América do Sul.

É necessário observar que esta nova ênfase na política exterior, especialmente relacionada à liberalização bilateral dos mercados, gerou muitos temores por causa da maior competitividade da indústria brasileira e pelo ingresso de produtos manufaturados provenientes da Zona Franca de Manaus; por isso, se faz inevitável estabelecer uma nova relação estratégica.

Toledo e Lula assinaram oito acordos bilaterais, sendo o mais relevante o Memorando de Entendimento sobre Integração Física e Econômica entre Peru e Brasil. Esse Memorando impulsionaria a integração das vias mediante a consolidação de três eixos para a comunicação, integração e desenvolvimento que são o amazônico, o transoceânico central e o interoceânico do Sul. Ambos os governos se comprometeram a priorizar o financiamento com fontes próprias. Também se assinou um acordo que permitirá o Peru fazer parte do Sistema de Proteção e Vigilância Amazônica (SIVAM).

Com a finalidade de velar pelo cumprimento dos acordos, foi criado um novo mecanismo de consulta que substituiu o estabelecido em junho de 2001. Neste último, se considera reunião anual dos presidentes com seus respectivos gabinetes ministeriais. Esta instância significa um novo nível das relações Peru-Brasil com miras a consolidar uma aliança estratégica. Um dos sinais foi o apoio que o Peru deu para ser membro permanente do Conselho de Segurança da ONU e o apoio do Brasil ao Peru como membro não permanente da mesma entidade no período de 2006-2007.

\section{Estrutura do Comércio Internacional do Peru e do Brasil}

Peru e Brasil participam do Acordo Comercial Preferencial da Organização Mundial de Comércio (OMC). São também signatários do Acordo Comercial Relativo denominado "Protocolo Relativo às Negociações Comerciais entre Países em Desenvolvimento (PTN)", 
com fundamento jurídico na OMC — Cláusula de Habilitação que entrou em vigência em 11 de fevereiro de 1973 com composição Multilateral da Ásia Ocidental, da América do Sul, da Ásia Oriental, da África, do Oriente Médio, da América do Norte, da Europa. São igualmente membros da Associação Latino-Americana de Integração - ALADI tendo como Marco Normativo o Tratado de Montevidéu de 1980.

Estrutura do Comércio Internacional do Peru - O Peru é membro fundador da OMC e, segundo esta entidade, o país dá o tratamento de "Nações mais Favorecidas" a todos seus sócios comerciais. Entretanto, não faz parte de nenhum acordo multilateral da OMC, estando, porém, em processo de aceitar o acordo sobre Tecnologia da Informação. O Peru cumpre com seus compromissos internacionais, embora adote o comércio interno como política comercial.

Cabe ressaltar que tem como principais sócios comerciais os Estados Unidos e a China representando um terço do comércio de bens. Em 2008, os Estados Unidos mantiveram sua participação comercial, já a China aumentou de 11,4\% em 2007 para 12,7\% em 2008. No que se relaciona aos mercados de destino das exportações, China, Suíça, Equador e Itália aumentaram também sua participação.

Evolução das Exportações Peruanas - 2000 a 2008 - A estrutura de exportação do Peru está dividida, segundo fontes oficiais desse país como o Ministério de Comercio Exterior y Turismo e o Banco Central de Reserva del Peru em Produtos Tradicionais, compreendendo pescados, produtos agrícolas, minérios, petróleo cru e derivados, Produtos não Tradicionais classificados em agropecuários, pescados, têxteis, madeiras, papéis e manufaturados, químicos, minerais não metálicos, siderometalúrgicos e joalheria, metal mecânicos, Outras Exportações não Tradicionais e Outras Exportações, como mostra a Tabela 1.

No ano de 2000, as exportações FOB somaram US\$ 6,955 bilhões, aumentando em 2004 para US $\$ 12,900$ bilhões; em 2005 para US $\$ 17,366$ bilhões e manteve esse crescimento inclusive no final de 2008 fechando com US\$ 31,529 bilhões, representando 2,8\% do PIB; aumento que representou 13,1\% em relação a 2007.

Os principais sócios comerciais do Peru são os Estados Unidos e a China representando um terço do comércio externo de bens. Em termos de exportações, relativamente a 2007, os Estados Unidos mantiveram em 2008 a participação comercial, mas a China aumentou de 11,4 \% para 12,7\% nesses anos, o mesmo sucedendo com a Suíça e o Equador.

Evolução das Importações Peruanas - 2000 a 2008 - A estrutura de importação do Peru está dividida, segundo as mesmas fontes governamentais acima mencionadas Ministério de Comercio Exterior y Turismo e o Banco Central de Reserva del Peru, em Bens de Consumo, considerando os produtos finais de consumo, Bens Intermédios ou Insumos, abrangendo todos os recursos que se utilizam no processo de produção, Bens de Capital, ou seja, os que se utilizam na produção de outros bens de consumo ou investimento e que se depreciam ao longo do processo produtivo, Outros Bens, abrangendo os que não estão inclusos nos critérios acima indicados e Principais Alimentos como consta na Tabela 2.

O Peru aumentou as importações provenientes dos Estados Unidos, da China, do Japão e da Itália. Os acordos de livre comércio mais recentes são os assinados com o Chile e os Estados Unidos, sendo este país também o principal destino das exportações peruanas. 
Tabela n. 1

Evoluçẫo do perfil das Exportaçôes em MUSAD do Peru para o Mundo a partir do Ano 2000 até 2008

$\begin{array}{lrrrrrrrrr}\text { Ano } & 2000 & 2001 & 2002 & 2003 & 2004 & 2005 & 2006 & 2007 & 2008 \\ \text { Total Em MUSD } & 6.955 & 7.026 & 7.714 & 9.091 & 12.809 & 17.368 & 23.830 & 27.882 & 31.529 \\ \text { Produtos } & & & & & & & & & \\ \text { Tradicionais } & 4.804 & 4.730 & 5.369 & 6.356 & 9.199 & 12.950 & 18.461 & 21.464 & 23.796 \\ \text { Pesqueiros } & 955 & 926 & 892 & 821 & 1.104 & 1.303 & 1.335 & 1.460 & 1.791 \\ \text { Agrícolas } & 249 & 208 & 216 & 224 & 325 & 331 & 574 & 460 & 685 \\ \text { Mineiros } & 3.220 & 3.205 & 3.809 & 4.690 & 7.124 & 9.790 & 14.735 & 17.238 & 18.657 \\ \text { Petróleo Cru e derivados } & 381 & 391 & 451 & 621 & 646 & 1.526 & 1.818 & 2.307 & 2.663 \\ \text { Năo Tradicionais } & 2.044 & 2.183 & 2.256 & 2.620 & 3.479 & 4.277 & 5.279 & 6.303 & 7.543 \\ \text { Agropecuários } & 394 & 437 & 550 & 624 & 801 & 1.008 & 1.220 & 1.507 & 1.912 \\ \text { Pesqueiros } & 177 & 197 & 164 & 205 & 277 & 323 & 433 & 499 & 622 \\ \text { Téxteis } & 701 & 664 & 677 & 823 & 1.092 & 1.275 & 1.473 & 1.736 & 2.018 \\ \text { Madeiras, Papeis e Manufaturad } & 123 & 142 & 177 & 172 & 214 & 261 & 333 & 362 & 425 \\ \text { Químicos } & 212 & 247 & 256 & 316 & 415 & 538 & 602 & 805 & 1.041 \\ \text { Minerais Nắo Metálicos } & 47 & 58 & 68 & 74 & 95 & 118 & 135 & 165 & 176 \\ \text { Sidero-Metalúrgicos e Joalheria } & 265 & 243 & 222 & 262 & 391 & 493 & 829 & 906 & 908 \\ \text { Metal - Mecânicos } & 97 & 160 & 110 & 99 & 136 & 191 & 164 & 217 & 324 \\ \text { Outros XNT } & 29 & 36 & 33 & 45 & 58 & 70 & 89 & 107 & 118 \\ \text { Outras Exp. } & 107 & 113 & 89 & 114 & 132 & 141 & 91 & 115 & 190\end{array}$

Fonte: Banco Centrai de Reserva dei Perú, adaptado

Tabela n. 2

Evoluçẫo do perfil das Importaçốes em MUSAD do Mundo pelo Peru a partir de 2000 até 2008

$\begin{array}{lrrrrrrrrr}\text { Ano } & 2000 & 2001 & 2002 & 2003 & 2004 & 2005 & 2006 & 2007 & 2008 \\ \text { Total Em MUSD } & 7.358 & 7.205 & 7.393 & 8.205 & 9.805 & 12.082 & 14.844 & 19.595 & 28.439 \\ \text { Produtos } & & & & & & & & & \\ \text { Bens de Consumo } & 1.494 & 1.635 & 1.754 & 1.841 & 1.995 & 2.308 & 2.616 & 3.192 & 4.527 \\ \text { Insumos } & 3.611 & 3.551 & 3.740 & 4.340 & 5.364 & 6.600 & 7.981 & 10.435 & 14.553 \\ \text { Bens de Capital } & 2.114 & 1.921 & 1.842 & 1.974 & 2.361 & 3.064 & 4.123 & 5.861 & 9.239 \\ \text { Outros Bens } & 139 & 97 & 56 & 49 & 85 & 110 & 123 & 107 & 120 \\ \text { Principais Alimentos } & 458 & 504 & 546 & 560 & 722 & 747 & 880 & 1.203 & 1.703\end{array}$

Fonte: Banco Centrai de Reserva del Perú, adaptado

Estrutura do Comércio Internacional do Brasil — O Brasil é membro fundador da OMC e sua atuação vem se destacando desde a associação ao GATT. O país é também membro originário da ALADI e faz parte do G20, que nasceu pela demanda de uma maior participação na $\mathrm{OMC}$ dos países emergentes especialmente no relacionado à agricultura. Igualmente faz parte do BRIC, juntamente com a Rússia, a Índia e a China e apresenta potencial para se tornar a maior força da economia mundial.

Evolução das Exportações Brasileiras — 2000 a 2008 - A estrutura das exportações brasileiras é classificada por Fator Agregado e/ou Produtos Industriais por aplicação da tecnologia, segundo fontes oficiais como o Ministério de Desenvolvimento, Indústria e Comércio Exterior do Brasil. Assim, constam na Tabela 6:

a) Indústria de Alta Tecnologia que engloba os subprodutos: aeronáuticos e aeroespaciais; farmacêuticos; material de escritório e informática; equipamento de radio, TV e comunicação; instrumentos médicos de ótica e precisão;

b) Indústria de Média-Alta Tecnologia que reúne produtos como: máquinas e equipamentos elétricos não especificados; veículos automotores, reboques e semirreboques; 
produtos químicos, excluindo os farmacêuticos; equipamento para ferrovia e material de transporte não especificados; máquinas e equipamentos mecânicos não especificados;

c) Indústria de Média-Baixa Tecnologia: construção e reparação naval; borracha e produtos plásticos; produtos de petróleo refinado e outros combustíveis; outros produtos minerais não metálicos; produtos metálicos;

d) Indústria de Baixa tecnologia que reúne: produtos manufaturados não especificados e bens reciclados; madeira e seus produtos, papel celulose; alimentos, bebidas e tabacos; têxteis, couro e calçados;

e) produtos não Industriais.

O Brasil elevou a participação no comércio internacional na última década, especialmente a partir do ano de 2000, no que concerne aos produtos básicos, semimanufaturados e manufaturados, como se pode observar na Tabela 3. Segundo Fonseca (2005), esta expansão se deve ao crescimento generalizado do coeficiente de exportação na maioria dos setores industriais, no período de 2000 a 2004 de $11,5 \%$ a $17,5 \%$ respectivamente a preços constantes.

Segundo o Ministério do Desenvolvimento, Indústria e Comércio Exterior, as exportações brasileiras de produtos básicos, semimanufaturados e manufaturados para o mundo no final do ano 2000 eram de 55.086 bilhões de dólares e se mantiveram em expansão com pequena variação no início da década e aumentaram significativamente nos anos 2003, 2004 e 2005 com uma variação de $21,1 \% ; 32 \%$ e 22,6\% respectivamente, mantendo seu crescimento até o 2008 e, apesar da crise mundial do último semestre desse ano, culminou o ano com 197,9 bilhões de dólares.

\section{Tabela n. 3}

Evoluçẫo do Perfil das Exportaçỗes em MUSAD de Brasil para o Mundo a partir do ano 2000 até 2008

\begin{tabular}{|c|c|c|c|c|c|c|c|c|c|}
\hline Ano & 2000 & 2001 & 2002 & 2003 & 2004 & 2005 & 2006 & 2007 & 2008 \\
\hline Total & 55.086 & 58.223 & 60.362 & 73.084 & 96.475 & 118.308 & 137.470 & 160.649 & 197.942 \\
\hline Produtos industriais ( ${ }^{*}$ ) & 45.968 & 47.748 & 48.652 & 58.504 & 77.137 & 94.016 & 107.320 & 121.908 & 141.890 \\
\hline Industria de alta e média-alta tecnologia $(1+\|)$ & 19.589 & 19.300 & 18.870 & 21.829 & 28.905 & 37.669 & 41.768 & 46.760 & 51.630 \\
\hline Indústria de alta tecnologia (I) & 6.838 & 6.982 & 5.935 & 5.135 & 6.610 & 8.757 & 9.364 & 10.241 & 11.507 \\
\hline Aeronáutica e aeroespacial & 3.681 & 3.709 & 2.835 & 2.107 & 3.478 & 3.699 & 3.741 & 5.204 & 6.064 \\
\hline Farmacêutica & 403 & 425 & 440 & 476 & 590 & 725 & 905 & 1.134 & 1.482 \\
\hline Material de escritório e informática & 490 & 395 & 236 & 271 & 334 & 478 & 496 & 273 & 235 \\
\hline Equipamentos de rádio, TV e comunicação & 1.904 & 2.075 & 2.079 & 1.949 & 1.789 & 3.332 & 3.579 & 2.863 & 2.871 \\
\hline Instrumentos médicos de ótica e precisẫo & 361 & 379 & 345 & 332 & 421 & 523 & 643 & 767 & 854 \\
\hline Indústria de média-alta tecnologia (II) & 12.751 & 12.317 & 12.935 & 16.694 & 22.295 & 28.912 & 32.403 & 36.519 & 40.123 \\
\hline Máquinas e equipamentos elétricos n. e. & 928 & 1.011 & 936 & 1.113 & 1.418 & 1.953 & 2.618 & 3.200 & 3.777 \\
\hline Veículos automotores, reboques e semi-reboques & 5.349 & 5.360 & 5.530 & 7.262 & 9.634 & 12.992 & 14.371 & 15.009 & 16.293 \\
\hline Produtos químicos, excl. farmacêuticos & 3.331 & 2.851 & 3.147 & 3.930 & 4.817 & 5.984 & 6.800 & 8.181 & 8.772 \\
\hline Equipamentos para ferrovia e material de transporte n. e. & 117 & 124 & 130 & 199 & 289 & 560 & 532 & 578 & 496 \\
\hline Máquinas e equipamentos mecânicos n. e. & 3.026 & 2.972 & 3.193 & 4.190 & 6.136 & 7.424 & 8.082 & 9.550 & 10.785 \\
\hline Indústria de média-baixa tecnologia (III) & 10.227 & 9.985 & 10.650 & 13.394 & 18.847 & 22.741 & 27.252 & 31.599 & 38.870 \\
\hline Construçã̃o e reparaçẫo naval & 7 & 38 & 9 & 8 & 1.265 & 194 & 30 & 724 & 1.541 \\
\hline Borracha e produtos plásticos & 955 & 941 & 922 & 1.169 & 1.398 & 1.709 & 2.050 & 2.569 & 2.870 \\
\hline Produtos de petróleo refinado e outros combustiveis & 1.713 & 2.408 & 2.176 & 2.780 & 3.203 & 4.914 & 6.109 & 7.136 & 9.489 \\
\hline Outros produtos minerais não-metálicos & 852 & 814 & 937 & 1.129 & 1.502 & 1.775 & 2.114 & 2.288 & 2.080 \\
\hline Produtos metálicos & 6.699 & 5.784 & 6.605 & 8.307 & 11.479 & 14.149 & 16.949 & 18.882 & 22.891 \\
\hline Indústria de baixa tecnologia (IV) & 16.152 & 18.464 & 19.132 & 23.281 & 29.384 & 33.606 & 38.300 & 43.549 & 51.389 \\
\hline Produtos manufaturados n.e. e bens reciclados & 884 & 906 & 910 & 1.038 & 1.422 & 1.516 & 1.558 & 1.718 & 1.759 \\
\hline Madeira e seus produtos, papel e celulose & 4.040 & 3.701 & 3.837 & 4.960 & 6.003 & 6.503 & 7.232 & 8.125 & 8.651 \\
\hline Alimentos, bebidas e tabaco & 7.685 & 10.149 & 10.830 & 13.188 & 17.141 & 20.492 & 23.967 & 27.667 & 35.373 \\
\hline Têxteis, couro e calçados & 3.543 & 3.708 & 3.555 & 4.094 & 4.819 & 5.095 & 5.542 & 6.039 & 5.607 \\
\hline Produtos näo industriais & 9.118 & 10.474 & 11.709 & 14.580 & 19.339 & 24.292 & 30.150 & 38.741 & 56.053 \\
\hline
\end{tabular}

Fonte: SECEXAMDIC, adaptado 
Evolução das Importações Brasileiras por Fator Agregado — 2000 a 2008 - A estrutura das importações brasileiras apresenta a mesma classificação das exportações conforme se pode observar na Tabela 4. Atingiram 173,2 bilhões de dólares em 2008. Segundo o Ministério de Desenvolvimento, Indústria e Comércio Exterior estes números significam prosseguimento do nível de abertura da economia e maior inserção brasileira no comércio mundial, como se pode ver na Tabela 7. Mas é necessário ressaltar que o Brasil, por ter uma das economias mais fechadas quando comparado com os outros países latino-americanos, ao longo do início deste século, impôs salvaguardas para vários produtos provenientes do Peru, com a finalidade de proteger a produção nacional. Também reduziu os tributos de importação de alguns produtos como, por exemplo, cimento e álcool combustível, favorecendo esses segmentos.

Tabela n. 4

Evoluçẫo do Perfil das Importaçỗes em MUSAD do Mundo pelo Brasil do ano 2000 até 2008

\begin{tabular}{|c|c|c|c|c|c|c|c|c|c|}
\hline Ano & 2000 & 2001 & 2002 & 2003 & 2004 & 2005 & 2006 & 2007 & 2008 \\
\hline Total & 55.851 & 55.602 & 47.243 & 48.326 & 62.836 & 73.600 & 91.349 & 120.621 & 173.196 \\
\hline Produtos industriais & 49.136 & 49.219 & 40.652 & 40.537 & 51.626 & 60.781 & 75.069 & 99.950 & 143.184 \\
\hline Industria de alta e média-alta tecnologia $(|+| \mid)$ & 35.627 & 36.860 & 30.330 & 30.418 & 38.901 & 45.552 & 54.514 & 71.929 & 102.731 \\
\hline Indústria de alta tecnologia (I) & 14.180 & 13.824 & 10.460 & 10.431 & 14.158 & 17.134 & 21.203 & 25.284 & 33.439 \\
\hline Aeronáutica e aeroespacial & 1.841 & 1.766 & 1.227 & 1.117 & 1.722 & 1.954 & 2.415 & 3.420 & 4.950 \\
\hline Farmacêutica & 2.381 & 2.557 & 2.328 & 2.257 & 2.683 & 3.005 & 3.623 & 4.898 & 6.124 \\
\hline Material de escritório e informática & 1.962 & 1.828 & 1.405 & 1.321 & 1.566 & 2.027 & 2.719 & 2.656 & 3.340 \\
\hline Equipamentos de rádio, TV e comunicação & 6.072 & 5.367 & 3.533 & 3.859 & 5.757 & 7.216 & 8.874 & 9.492 & 12.657 \\
\hline Instrumentos médicos de ótica e precisã̃o & 1.924 & 2.306 & 1.967 & 1.877 & 2.430 & 2.932 & 3.573 & 4.819 & 6.367 \\
\hline Indústria de média-alta tecnologia (II) & 21.446 & 23.036 & 19.870 & 19.987 & 24.743 & 28.418 & 33.311 & 46.645 & 69.292 \\
\hline Máquinas e equipamentos elétricos $\mathrm{n}$. e. & 2.743 & 3.833 & 3.098 & 2.657 & 2.657 & 2.897 & 3.526 & 4.466 & 6.116 \\
\hline Veículos automotores, reboques e semi-reboques & 4.377 & 4.368 & 3.230 & 3.136 & 3.940 & 5.167 & 6.535 & 9.273 & 14.091 \\
\hline Produtos químicos,excl. farmacêuticos & 8.189 & 8.074 & 7.634 & 8.625 & 11.641 & 12.149 & 13.596 & 19.033 & 28.881 \\
\hline Equipamentos para ferrovia e material de transporte $n$. e. & 254 & 228 & 206 & 151 & 290 & 429 & 559 & 644 & 1.262 \\
\hline Máquinas e equipamentos mecânicos n. e. & 5.884 & 6.534 & 5.702 & 5.419 & 6.214 & 7.775 & 9.096 & 13.229 & 18.942 \\
\hline Indústria de média-baixa tecnologia (III) & 8.793 & 8.260 & 6.671 & 6.800 & 8.665 & 10.484 & 14.339 & 19.649 & 29.221 \\
\hline Construçã̃o e reparação naval & 14 & 36 & 56 & 115 & 14 & 22 & 24 & 55 & 72 \\
\hline Borracha e produtos plásticos & 1.297 & 1.287 & 1.219 & 1.267 & 1.574 & 1.929 & 2.219 & 2.887 & 4.013 \\
\hline Produtos de petróleo refinado e outros combustiveis & 4.463 & 3.754 & 2.744 & 2.580 & 3.202 & 3.687 & 5.265 & 7.254 & 12.196 \\
\hline Outros produtos minerais nã̃o-metálicos & 419 & 421 & 370 & 414 & 513 & 581 & 649 & 874 & 1.210 \\
\hline Produtos metálicos & 2.601 & 2.762 & 2.282 & 2.424 & 3.361 & 4.265 & 6.181 & 8.579 & 11.731 \\
\hline Indústria de baixa tecnologia (IV) & 4.716 & 4.099 & 3.651 & 3.319 & 4.060 & 4.744 & 6.216 & 8.372 & 11.232 \\
\hline Produtos manufaturados n.e. e bens reciclados & 414 & 391 & 332 & 291 & 393 & 467 & 625 & 940 & 1.291 \\
\hline Madeira e seus produtos, papel e celulose & 1.281 & 1.043 & 869 & 727 & 941 & 1.089 & 1.396 & 1.638 & 2.079 \\
\hline Alimentos, bebidas e tabaco & 1.950 & 1.620 & 1.605 & 1.489 & 1.667 & 1.816 & 2.281 & 3.020 & 4.080 \\
\hline Têxteis, couro e calçados & 1.072 & 1.045 & 845 & 812 & 1.059 & 1.373 & 1.913 & 2.774 & 3.782 \\
\hline Produtos não industriais & 6.714 & 6.383 & 6.590 & 7.789 & 11.210 & 12.819 & 16.281 & 20.671 & 30.012 \\
\hline
\end{tabular}

Fonte: SECEXAMDIC, adaptado

\section{Estrutura do Comércio Bilateral Brasil-Peru}

Entre 1998 e 2002, houve uma tendência de desaceleração do comércio bilateral entre Peru e Brasil, com recuperação a partir de 2003 e atingindo em 2008 o equivalente a 3 bilhões de dólares, representando acréscimo de $22 \%$ em relação a 2007, segundo o Ministério de Desenvolvimento, Indústria e Comércio Exterior do Brasil. Ainda assim, o nível das exportações ao Brasil sempre foi baixo, representando apenas o 2,6\% das exportações totais do Peru.

Com a finalidade de padronizar os dados baseados na premissa de integração comercial bilateral entre os dois países latino-americanos, este trabalho considerou como base os 
informes disponibilizados pela Associação Latino-Americana de Integração — ALADI por ser uma das entidades que tenta encontrar convergências econômicas dos países associados, entre os quais estão incluídos o Peru e Brasil.

Para o ponto de análise seguinte, foram utilizados, por motivos metodológicos, apenas os dados consolidados da evolução das exportações e importações por fator agregado Brasil-Peru. Por outro lado, objetivando facilitar a visualização das contradições entre os dois países com relação aos valores e à descrição dos itens existentes, são apresentadas separadamente as tabelas relacionadas às exportações e importações segundo fontes oficiais de cada país.

Evolução da Pauta das Exportações e Importações do Peru — 2000 a 2008 Os produtos mais exportados do Peru para o Brasil são os tradicionais, essencialmente as matérias-primas, que representaram $82 \%$ até 2002 e aumentaram para $85 \%$ no final de 2006 . Até 1997, as exportações para o Brasil foram crescendo até atingir 256 milhões de dólares. Já a partir de 1998 até 2002, houve uma queda, chegando a 196 milhões de dólares neste ano. Esta baixa esteve relacionada às sucessivas crises internacionais como a asiática, a russa, a brasileira e a recessão norte-americana que afetaram a região. A partir de 2003, houve um crescimento contínuo da exportação, atingindo em 2006 a soma de 814,52 milhões de dólares, ou incremento de $78 \%$ em relação a 2005 .

As exportações do setor tradicional representaram 665,13 milhões de dólares em 2006, um aumento de $73 \%$ em relação a 2005 , como se pode verificar na Tabela 5 . Este setor foi sustentado pelos produtos mineiros que totalizaram 655,35 milhões de dólares, aumentando assim em 75,6\% em relação ao ano anterior. Em 2008, o Peru exportou para o Brasil o montante de 956 milhões de dólares continuando com a maior demanda o setor mineiro.

As exportações do setor não tradicional apresentaram em 2006 um total de 149,39 milhões de dólares, representando um aumento de $93 \%$. Este crescimento foi sustentado pelo setor da pesca. Exportação de maior quantidade de conservas de peixe que se incrementou em 327,2\%, de 1,96 milhões de dólares em 2005 para 8,39 milhões de dólares em 2006. Em 2008, esse setor não tradicional incrementou as exportações passando para 213 milhões de dólares em relação a 2007 que era de 126 milhões representados na sua maioria pelos subsetores siderometalúrgico, químico, agropecuário e agroindustrial.

As exportações do setor agropecuário para o Brasil foram de 14,67 milhões de dólares em 2006, 35,3\% a mais que em 2005, sendo os produtos mais representativos, azeitonas, tara e orégano. Em 2008, os produtos não tradicionais, que também fizeram parte da maior demanda do Brasil, foram os setores Têxtil e Confecção, e o Pesqueiro.

A Tabela 5 e a Tabela 6 mostram com mais detalhe a evolução das Exportações e Importações entre Peru e Brasil segundo fontes oficiais de Peru, no período 2000 a 2008. 
Tabela n. 5

Evoluçẫo das Exportaçỗes por Fatores em MUSAD segundo o Peru a partir do ano 2000 até 2008

\begin{tabular}{rrrrrrr} 
ANO & \multicolumn{2}{c}{ Total } & \multicolumn{2}{c}{ Tradicional } & \multicolumn{2}{c}{ Nẫo Tradicional } \\
& F.O.日. & Var. $\%$ & F.O.日. & Var. $\%$ & F.0.日. & \multicolumn{1}{c}{ Var. $\%$} \\
2000 & 221 & & 159 & & 40 & \\
2001 & 227 & $2,8 \%$ & 177 & $11,4 \%$ & 50 & $24,1 \%$ \\
2002 & 194 & $-14,6 \%$ & 151 & $-15,1 \%$ & 43 & $-13,1 \%$ \\
2003 & 231 & $19,2 \%$ & 184 & $22,4 \%$ & 47 & $8,8 \%$ \\
2004 & 356 & $54,0 \%$ & 283 & $53,7 \%$ & 73 & $55,3 \%$ \\
2005 & 453 & $27,3 \%$ & 381 & $34,4 \%$ & 77 & $5,9 \%$ \\
2006 & 809 & $78,6 \%$ & 656 & $72,4 \%$ & 149 & $93,3 \%$ \\
2007 & 938 & $15,9 \%$ & 806 & $22,9 \%$ & 126 & $-15,6 \%$ \\
2008 & 895 & $-4,5 \%$ & 682 & $-15,4 \%$ & 213 & $69,2 \%$
\end{tabular}

Fonte:PROMPEX, adaptado

Tabela n. 6

Evoluçẫo das Importaçỗes Totais segundo o Peru a partir do ano 2000 até 2008 em MUSAD

$\begin{array}{lrrrrrrrrr}\text { Ano } & 2000 & 2001 & 2002 & 2003 & 2004 & 2005 & 2006 & 2007 & 2008 \\ \text { Total F.0.B } & 378 & 298 & 448 & 608 & 636 & 940 & 1.497 & 1.757 & 2.272 \\ \text { Variaçẵo } & & -21,1 \% & 50,3 \% & 35,6 \% & 4,5 \% & 47,9 \% & 59,3 \% & 17,4 \% & 29,3 \%\end{array}$

Fontes: CAN, SUNAT, adaptado.

Evolução das Exportações e das Importações Brasileiras — 2000 a 2008 - Do ano de 1995 até 2001 , as exportações brasileiras se mantiveram constantes, aproximadamente de 300 milhões de dólares. Em 2002, ocorreu um acréscimo de 39,3\% chegando a 392 milhões de dólares, o mais alto dos 10 últimos anos. Este aumento se deveu à aquisição do gasoduto para o projeto do Gás de Camisea, que teve um custo estimado de 50 milhões, o restante foi em razão do aumento da exportação de bens de capital representando 48,4\% do total.

O crescimento do intercâmbio comercial entre os dois países se manteve durante os seguintes. Em 2004 e 2005, as exportações somaram 633 milhões e 943,1 milhões de dólares respectivamente, sempre sustentados na maior parte pelos bens de consumo, produtos intermediários e bens de capital. Já em 2008, o Brasil exportou para o Peru 2,500 bilhões composto por $81,4 \%$ dos produtos industrializados e $18,4 \%$ de intermédios. Considerando o destino dos produtos brasileiros, o Peru ocupou o $30^{\circ}$ lugar nesse ano.

Como se pode perceber, as exportações para o Peru são baseadas em produtos de fator agregado como bens de consumo não duráveis e bens de consumo duráveis. A nação peruana praticamente não exporta matérias-primas e sim produtos intermédios, relacionados à tecnologia nos diferentes setores como petróleo, aço, carros, escavadeiras e outros para uso em minas subterrâneas e/ou construção.

A Tabela 7 e a Tabela 8 ilustram melhor a evolução das exportações por fator agregado e importações totais do intercâmbio comercial conforme informações das fontes oficiais do Brasil no período 2000 até 2008. 


\section{Tabela n. 7}

Evoluçẫo das Exportaçỗes em MUSAD por Fator Agregado segundo o Brasil do ano 2000 até 2008

\begin{tabular}{|c|c|c|c|c|c|c|c|c|c|}
\hline & \multicolumn{2}{|c|}{ Total } & \multicolumn{2}{|c|}{ Exp.Básicos } & \multirow{2}{*}{$\begin{array}{l}\text { Sub Total } \\
\text { F.O.日 }\end{array}$} & \multicolumn{2}{|c|}{ Semi-manufaturados } & \multicolumn{2}{|c|}{ Faturados } \\
\hline & F.O.B & Var. $\%$ & F.O.B & Var. $\%$ & & F.O.B & Var. $\%$ & F.O.B & Var. $\%$ \\
\hline 2000 & 353 & 33,2 & 6 & $-9,7$ & 346 & 7 & 1,9 & 339 & 35,3 \\
\hline 2001 & 286 & $-18,9$ & 11 & 78,0 & 275 & 7 & 0,5 & 268 & $-21,1$ \\
\hline 2002 & 436 & 52,3 & 9 & $-19,4$ & 427 & 7 & 5,9 & 419 & 56,6 \\
\hline 2003 & 488 & 11,9 & 37 & 301,1 & 451 & 9 & 23,2 & 442 & 5,4 \\
\hline 2004 & 636 & 29,4 & 59 & 61,4 & 574 & 14 & 50,2 & 561 & 25,9 \\
\hline 2005 & 939 & 47,6 & 133 & 125,1 & 791 & 14 & 5,3 & 777 & 38,5 \\
\hline 2006 & 1.510 & 60,8 & 379 & 184,5 & 1.117 & 31 & 114,4 & 1.087 & 39,9 \\
\hline 2007 & 1.649 & 9,2 & 315 & $-17,0$ & 1.325 & 28 & $-7,7$ & 1.297 & 19,4 \\
\hline 2008 & 2.299 & 39,4 & 417 & 32,6 & 1.880 & 41 & 45,4 & 1.839 & 41,8 \\
\hline
\end{tabular}

Fonte: SECEX, adaptado

Tabela n. 8

Evoluçẫo das Importaçốes Totais em MUSAD segundo Brasil a partir do ano 2000 até 2008

$\begin{array}{lrrrrrrrrr}\text { Ano } & 2000 & 2001 & 2002 & 2003 & 2004 & 2005 & 2006 & 2007 & 2008 \\ \text { MUSAD } & 211 & 231 & 218 & 235 & 349 & 459 & 788 & 996 & 956 \\ \text { Variaçẫo } & & 9,2 \% & -5,6 \% & 8,0 \% & 48,5 \% & 31,4 \% & 71,7 \% & 26,4 \% & -4,0 \%\end{array}$

Fonte SECEXMDIC, adaptado

Cabe ressaltar a existência de contradições entre os dados dos valores oficiais fornecidos pelo Peru e pelo Brasil, sendo quase sempre maior a quantidade de importação segundo o país informante. Para poderem ser visualizadas mais claramente tais contradições se apresentam o Gráfico 1 e o Gráfico 2. Apesar de, percentualmente, as variações não serem expressivas deve ser considerado que significam milhões de dólares de diferença. Por outro lado, para não existir esses tipos de contradições é necessária a convergência normativa e reguladora de ambos os países de modo a melhorar a harmonização do intercâmbio comercial. 
Gráfico 1: Comparativo Exportações segundo as Estatísticas Brasileiras e as Importações segundo as Fontes Peruanas (em MUSAD)

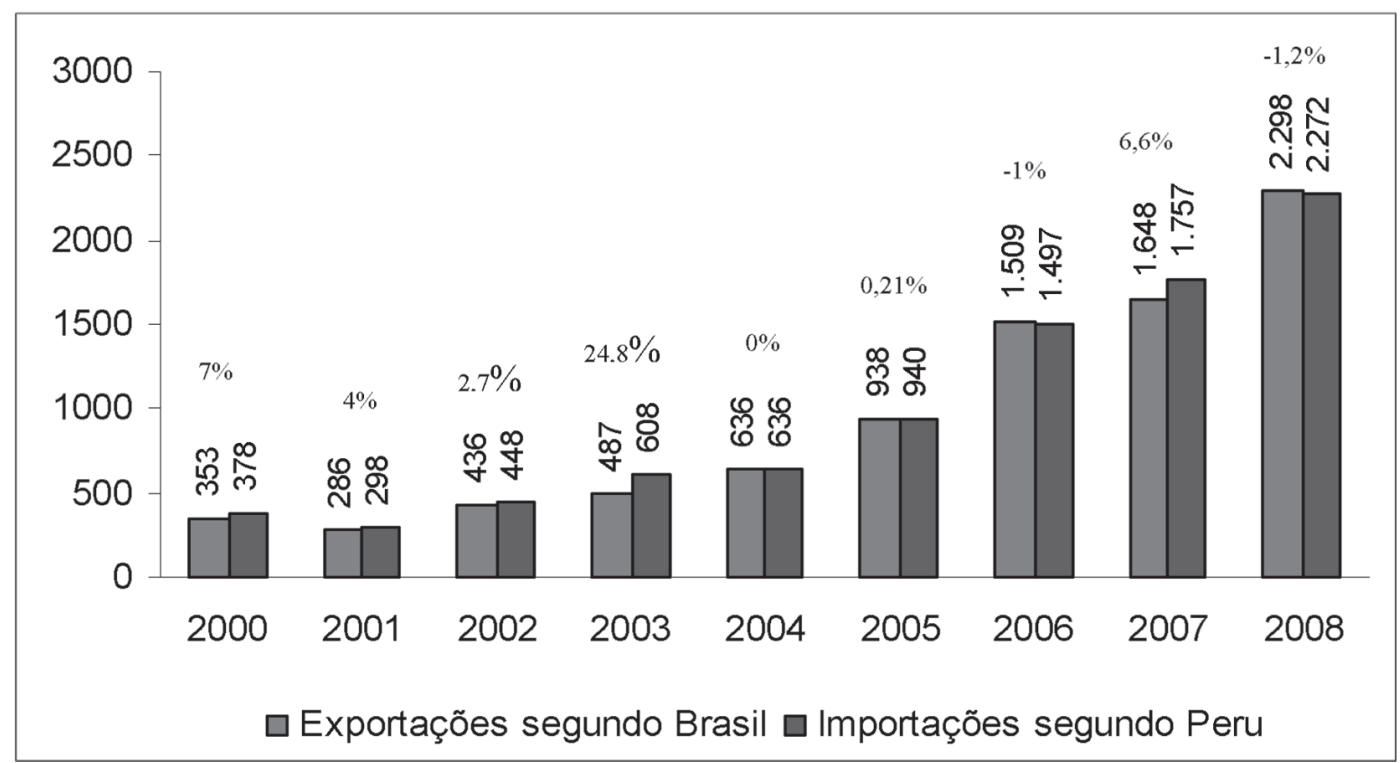

Fonte: SECEX e SUNAT.

Elaboração própria.

Gráfico 2: Comparativo Exportações segundo as Fontes Peruanas e as Importações segundo as Estatísticas Brasieiras (em MUSAD)

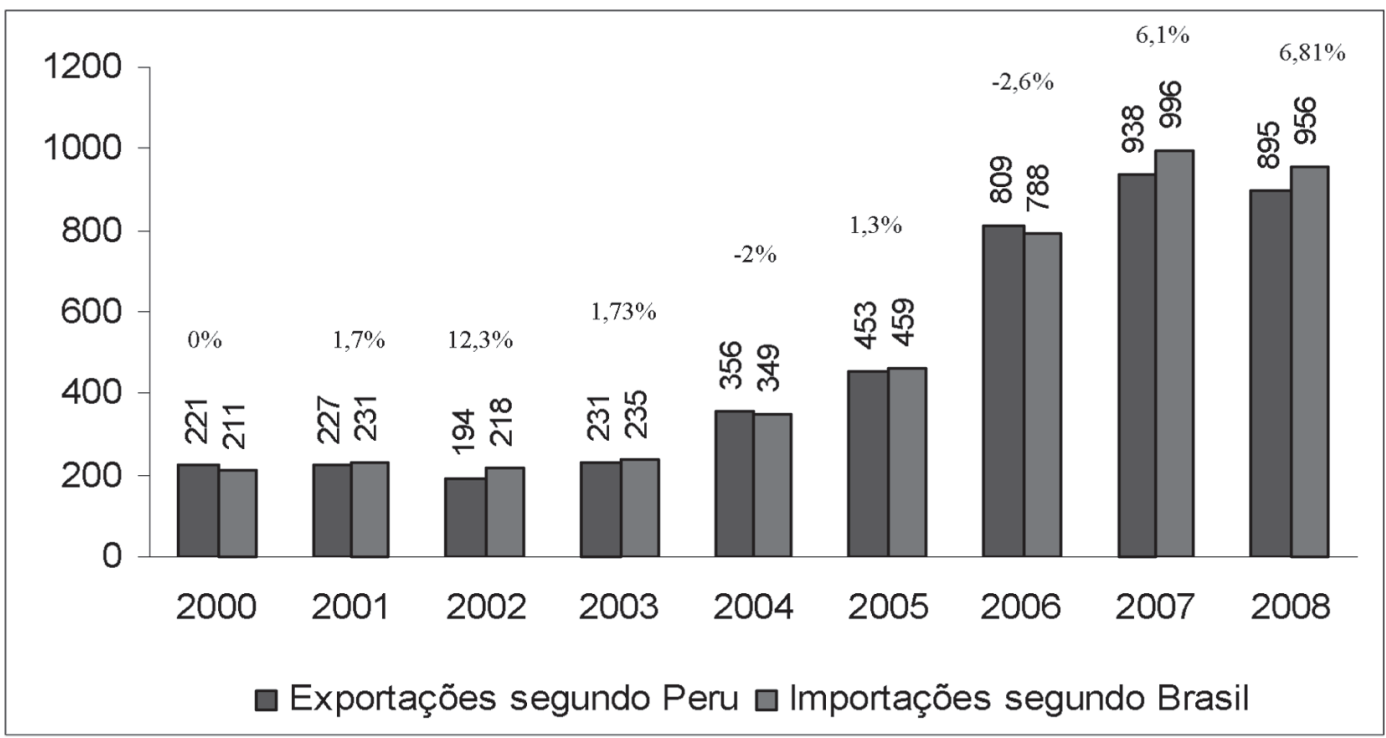

Fonte: SECEX e SUNAT.

Elaboração própria. 


\section{Tendências do Intercâmbio Comercial Peru-Brasil}

Os números relacionados ao comércio exterior vêm aumentando ligeiramente nos últimos anos. Esta tendência pode ter uma oscilação dependendo dos cenários em que possam se desenvolver as economias peruana e brasileira. Isso significa que, no caso de um cenário otimista, evidentemente, o comércio exterior para as duas nações também se ampliaria. Esta expansão seria menor em um cenário considerado normal ou médio, e aumentaria menos ainda se o cenário for pessimista. Especificamente, o Brasil poderia comprar do Peru em curto prazo, por exemplo, o cobre, como já o fazia anos atrás quando a Mineiro Peru abriu um escritório em São Paulo; ou os fosfatos de Sechura; e mais para frente o gás de Camisea. Poderiam também entrar no comércio produtos menos pesados, como o algodão apreciado pela sua qualidade ímpar; plantas e ervas medicinais, como a maca e unha de gato; ou ainda alimentos como a quinua, que já mostram uma grande aceitação entre os consumidores exigentes, existindo um nicho de mercado para os conhecedores deste tipo de produto.

Assim, é evidente que as exportações brasileiras são de produtos manufaturados e as exportações peruanas se sustentam mais com a exportação de produtos tradicionais. Existe uma grande probabilidade de que as exportações peruanas de produtos não tradicionais se incrementem, já que passaram de 16\% em 2007 para 27\% em 2008. Os exportadores peruanos veem o Brasil como um mercado de grandes oportunidades para crescer, com uma população de quase 200 milhões de habitantes, com uma renda per capita de aproximadamente 9,700 dólares anuais, sendo considerado um dos mercados mais importantes da América Latina, especialmente porque está em processo de abertura da economia. Já os exportadores brasileiros veem o Peru como ponto facilitador para comercializar com a Ásia, motivo que demandará melhorar os portos e as vias de comunicação desse país.

\section{Formas de Incentivar o Comércio Exterior entre Peru e Brasil}

Como forma de incentivar o comércio bilateral entre os dois países, é necessário criar mecanismos normativos, que possam influenciar no aumento dos volumes comercializados de produtos e serviços, que poderiam ser acionados pelos governos de ambos os países.

Dando início a essas formas de incentivo, por exemplo, a Embaixada do Peru no Brasil elaborou uma relação de produtos que agregariam as probabilidades de comércio entre os dois países. Para dar continuidade a esse processo foram organizados diferentes eventos pelos representantes do Peru, tanto nesse país quanto no Brasil, especialmente durante os últimos oito anos com o objetivo de melhor informar aos empresários brasileiros a respeito das vantagens comerciais que oferece.

Por sua parte, o governo brasileiro também está consciente do baixo nível do comércio com os países andinos. A título de ilustração, por exemplo, o Investimento Estrangeiro Direto do Brasil no vizinho país em 2008 foi de 342 milhões de dólares significando apenas o 1,91\% do Investimento Estrangeiro Direto Total. Para amenizar esse vazio, elaborou um estudo, por meio do FUNCEX — Fundo de Promoção do Comércio Exterior, com a 
finalidade de identificar setores, subsetores e bens específicos, que apresentam demanda no Brasil, para que potenciais exportadores do Grupo Andino possam tomar interesse em fazê-lo.

Rios \& Ribeiro, ao tratarem do Peru, indicam o seguinte:

“... En el caso del Perú fueron seleccionados 33 productos cuyas exportaciones fueron de US\$ 746 millones en 2003-2004 (4,3\% del total del país), siendo que apenas US\$ 1,2 millón es direccionada al Brasil, significando apenas 0,3\% del total que el Brasil importo de estos productos. Casi mitad de los productos (16) fue agrupada en la categoría de productos de vestuario, que incluye camisas, camisetas, pantalones, chompas y otros productos, tanto de algodón cuanto de fibras sintéticas. En todos los casos, sin embargo, el valor que el Perú exporta para el Brasil es cero o próximo de cero." (Rios \& Ribeiro, 2006, p. 59-60.)

Esta indicação de Rios \& Ribeiro mudou ao longo dos últimos anos. Ambos os governos assinaram vários Acordos e Memorandos de Entendimento para que o intercâmbio melhorasse e também para dar continuidade à política de expansão comercial dos dois países.

Tanto para o Peru quanto para o Brasil, a inclusão no comércio global constitui um elemento-chave para o crescimento econômico deles. Na reportagem da Economia e Desenvolvimento 2004 (RED 2004), se postula que, para lograr uma inclusão internacional eficiente, é preciso que esta se dê em função do aumento da produtividade. Para isso acontecer, são necessários a ampliação estratégica do mercado regional, o compromisso de liberalização comercial crescente e o desenvolvimento das vias de comunicação. Sendo que este último processo já foi iniciado com a construção da Interoceânica, que é essencial para a integração física de ambos países.

Outra das estratégias seria a prática da redução das barreiras alfandegárias e não alfandegárias em muitos casos já determinadas por acordos comerciais, mas que só ficaram no papel ou na proposta, sendo necessária a sua vigência. A difusão das informações sobre trâmites de exportação de ambos os países certamente contribuiria neste processo.

\section{Intercâmbio de Serviços}

Serviço de Turismo - O turismo é uma atividade com importância econômica relevante em qualquer país, por gerar empregos e divisas com pouco investimento e em curto prazo. Esta atividade representa maior número de visitantes peruanos ao Brasil que o número de brasileiros que viajam com esse fim ao Peru; este intercâmbio está indicado na Tabela 9 .

\section{Tabela n. 9}

Evoluçẫo do Intercâmbio de Visitantes entre Peru e Brasil a partir de 2004 até 2008

\begin{tabular}{llccccc}
\multicolumn{2}{c}{ País } & \multicolumn{5}{c}{ Ano } \\
Origem & Destino & 2004 & 2005 & 2006 & 2007 & 2008 \\
Brasil & Peru & 33.327 & 42.291 & 44.092 & 52.515 & 62.902 \\
Peru & Brasil & 22.707 & 25.516 & 28.798 & 46.172 & 48.260
\end{tabular}

Fonte: MNCETUR 
Como se pode observar, o número de peruanos que visitam o Brasil é crescente ano após ano e com isso aumenta o déficit para o Peru e diminui para o Brasil sendo este dado relevante na área de intercâmbio de visitantes.

Intercâmbio Cultural e Científico - O Brasil tem centros superiores de estudo de alto prestígio nos quais estudam e trabalham muitos peruanos; isto se deve à política de abertura dessas instituições e também de bolsas de estudo, especialmente para a pós-graduação. $\mathrm{O}$ site $<$ www.thes.co.uk/worldrankings $>$ mostra que o Brasil também conta com prestigiados centros de pesquisa científica, como a Empresa Brasileira de Pesquisa Agropecuária EMBRAPA, o Instituto de Pesquisas Tecnológicas do Estado de São Paulo - IPT, o Instituto de Pesquisa da Energia Nuclear — IPEN, o Instituto Tecnológico de Aeronáutica — ITA além de outros não menos relevantes.

\section{Integração das Vias de Comunicação entre Peru e Brasil}

O Peru e o Brasil vivem praticamente de costas um para o outro, sem nenhuma via de comunicação física rápida economicamente acessível, que não seja a via aérea ou a fluvial, o que dificulta enormemente o comércio, o turismo e todo tipo de intercâmbio como o cultural.

Nesse sentido, a construção da estrada Interoceânica entre Peru e Brasil é um projeto urgente de longa data. O Brasil já conta com vias de primeira ordem como a BR-364 e BR-3 17 que chegam até Assis, cidade fronteiriça com Peru. O Peru apesar dos esforços, não conseguiu ainda construir o intervalo Puerto Maldonado - Iñapari, cidade fronteiriça, que complementa o casco urbano de Assis. A ponte que une essas duas cidades fronteiriças foi inaugurada em 2007. Adicionalmente, faltaria construir ou melhorar o trecho que vai de Puerto Maldonado até um porto do Pacífico, ainda não definido, mas provavelmente sendo San Juan. Para tornar realidade este projeto, o Banco de Desenvolvimento Econômico e Social — BNDES disponibilizou recursos da ordem de aproximadamente 900 milhões de dólares. Destarte, só faltam maior empenho e decisão política para concretizar tal obra de grande envergadura que beneficiaria o desenvolvimento econômico de ambos os países.

\section{Considerações Finais}

Independentemente dos problemas e das limitações que as diferentes tentativas de integração unilateral, bilateral, regional ou multilateral apresentaram através do tempo, existem fatores que sustentam a viabilidade e continuidade do processo de integração regional.

Apesar de a tradição e a cultura do Peru e do Brasil divergirem em vários aspectos, há concepções coincidentes sobre a Sociedade e o Estado. Também esses países têm em comum um marco jurídico e institucional garantido pela subscrição de Tratados que facilitam a adoção de estratégias, políticas e ações conjuntas para a negociação e definição de uma integração bilateral, começando pela comercial. Na realidade, se observa uma crescente participação e interesse da sociedade civil e uma maior inter-relação entre empresas e capitais intrarregionais que trabalham com o mercado regional. 
Por observação indireta, este estudo mostra que Peru e Brasil pretendem seguir uma estratégia múltipla e pragmática de negociações comerciais simultaneamente: Multilateral da OMC; Regional da ALCA; fortalecimento dos acordos sub-regionais como MERCOSUL, Comunidade Andina, Mercado Comum Centro-Americano e CARICOM; além dos acordos de reciprocidade ou bilateralismo. Assim, o desenvolvimento histórico do processo de integração econômica entre o Peru e o Brasil para qualquer um desses aspectos mostra que deverá ser necessário que ambos os países incrementem os fluxos de cooperação e, desse modo, melhorem as capacidades relacionadas ao comércio. Essas capacidades não seriam apenas para negociar, adaptar a mudanças ou administrar os acordos, mas também para aproveitar da melhor forma as oportunidades de acesso a novos mercados.

Quando observada a formação de blocos econômicos e políticos por países mais desenvolvidos, vê-se que a integração se deu por meio de diferentes fases. Tudo começa com a criação de uma área ou zona que se beneficia com certas preferências econômicas e/ou com Tratados de Livre Comércio. No caso do Peru e do Brasil, pode-se considerar que estão na fase de diálogo para homogeneizar a legislação econômica e comercial para, dessa forma, facilitar o conhecimento mútuo dos interesses e, assim, enfrentar os desafios que uma integração bilateral requer, por exemplo, o desenvolvimento de políticas sociais e laborais, e a possibilidade de uma posterior união monetária, econômica e política.

As medidas tomadas em comum no início e durante o desenvolvimento do processo de integração fomentam a confiança e a segurança de ambos os estados e os demais países limítrofes, pela estruturação das relações de amizade e cooperação entre eles.

Como o comércio bilateral pode incentivar a diminuição e o alívio da pobreza ao estimular a criação de empregos e dar impulso para incrementar o comércio, o turismo e outros segmentos, a complementaridade econômica entre Peru e Brasil pode elevar o potencial de crescimento econômico. Se o objetivo for a integração em qualquer área, inclusive na comercial, tais países deverão juntar esforços para gerar benefícios, havendo necessidade de redobrá-los nas áreas sociais, políticas e econômicas com o firme propósito de melhorar a articulação e convergência de políticas relacionadas a este processo, por exemplo, na colaboração transfronteiriça com projetos de infraestrutura, assim como a harmonização de regulamentos para intercâmbio comercial de produtos e serviços.

Segundo diferentes estudos sobre o tema, a integração apenas é possível graças à vontade explícita do poder político dos Estados participantes. Então, fica demonstrado que especialmente depois do ano 2000 a vontade política dos mandatários do Peru com Toledo e Alan García e, do Brasil, com Lula da Silva, este requisito sempre esteve presente neste processo, independentemente do grau ao qual se chegou. É necessário considerar o sentido de identidade da sociedade para que durante o desenvolvimento do processo este apoie as mudanças permitindo, assim, um maior dinamismo e racionalidade coletiva.

O acordo de integração comercial entre o Peru e o Brasil constitui um passo fundamental na cooperação mútua contra problemas em comum. O diálogo e o estabelecimento de acordos jurídicos para a colaboração em matéria de segurança facilitam o aprofundamento da confiança entre ambos.

É necessário enfatizar que a crise financeira internacional continua afetando as economias emergentes por meio de várias formas como, por exemplo, a diminuição da demanda externa 
e a restituição dos fluxos de capital. Entre outras consequências, ocorre a deteriorização da conta corrente, significando menores volumes de exportação e menores cotações, assim como restrições ao financiamento externo, por menores fluxos e maiores taxas de juros.

Nesse contexto, as economias mais vulneráveis que enfrentaram, durante os últimos anos, elevados déficits em conta corrente precisam de um mercado com maior controle do governo para funcionar com mais eficiência.

Os acordos regionais econômicos e/ou comerciais podem não ser os instrumentos mais eficazes para a integração dos países da América Latina como é caso do Peru e do Brasil, mas é o primeiro passo para aproximar esses países vizinhos, porém, atualmente, distantes.

\section{ReFERÊNCIAS Bibliográficas}

ALBUQUERQUE, J. A. G.; OLIVEIRA, H. A. (Orgs.). Relações internacionais e sua construção jurídica. Série Alca, vol. 1 "Alca: Aspectos Históricos, Jurídicos e Sociais". São Paulo: FTD, 1998.

ALBUQUERQUE, J. A. G. Alca na política externa brasileira. Política Externa. São Paulo, ago./out. 2001. Sessenta anos de política externa brasileira (1930-1990), vol. 2. São Paulo: Cultural; Nupri/USP; Fapesp, 1996

ARAỨJO, Leandro Rocha de (Org.). Blocos econômicos e de integração na América Latina, África e Ásia. Curitiba: Juruá, 2008.

BALASSA, Bela. Comércio internacional. Rio de Janeiro: Victor Publicações, 1970.

BELEVÁN McBRIDE, Harry (1990). Evolución de las relaciones del Perú con Brasil, Colombia y Ecuador en:Ramón Bahamonde (ed.), Relaciones del Perú con Brasil, Colombia y Ecuador. Lima: CEPEI, p. 3-26.

BUENO, Clodoaldo; CERVO, Amado Luiz. História da política exterior do Brasil. 2. ed. Brasília: Editora da Universidade de Brasília, 2002.

CAETANO, Gerardo; TAMBLER, Adrian; ARBOLEYA, Ignácio; ARTESIANO, Roberto. Estado de situación y perspectivas de las relaciones entre el Mercosur y la Unión Europea. In: ¿̨Hacia dónde van las relaciones entre América Latina y la Unión Europea? Cohesión social y acuerdos de asociación. Ciudad de México: Editora de La Asociación Latinoamericana de Organizaciones de Promoción Al Desarrollo, 2008.

CONJUNTURA ECONÔMICA, vol. 60, n. 12, dez. 2006.

COSTA, Gino F. Rasgos de la política exterior brasilera después de 1964. Lima: CEPEI, 1986.

COSTA, Gino F. Perú: Brasil a la búsqueda de un socio amazónico. En: Las relaciones económicas y diplomáticas del Brasil con sus vecinos de la Cuenca Amazónica 1974-1985. Documento de Trabajo, n. 9. Lima: CEPEI, 1987. p. 44-62.

Los retos de nuestras relaciones con Brasil. Análisis Internacional, vol. 10, mayo/ago. Lima: CEPEI, 1985, p. 74-92.

DALLARI, Pedro Bohomoletz de Abreu. O Mercosul perante o sistema constitucional brasileiro. In: BASSO, Maristela (Org.). Mercosul-Mercosur. Estudos em Homenagem a Fernando Henrique Cardoso. São Paulo: Atlas, 2007.

DANESE, Sérgio. Diplomacia presidencial. Rio de Janeiro: Topbooks, 1999. 
DURAND LAZO, Karina. Posibilidades de asociación estratégica Perú-Brasil en matéria de seguridad y protección amazónica. Tesis presentada para optar por el grado académico de Magister en Diplomacia. Lima: Academia Diplomática del Perú, 21 de noviembre de 2000.

EDWARDS, Sebastián. Why are Latin America's savings rates so low? An internacional comparative analysis. Journal of Development Economics, vol 51, n. 1, p. 5-43, oct. 1996.

GIAMBIAGI, Fabio. A política fiscal do governo lula em perspectiva histórica: qual é o limite para o aumento do gasto público. Rio de Janeiro: IPEA, mar. 2006.

GOMES, Eduardo Biacchi. Blocos econômicos: solução de controvérsias-análise comparativa da União Europeia e do Mercosul. Curitiba: Juruá, 2006.

HOBSBAUM, E. O século: vista aérea — olhar panorâmico. Era dos extremos - o breve século XX - 1914-1991. São Paulo: Cia. das Letras, 1995, p. 11-26.

. Rumo ao milênio. Era dos extremos — o breve século XX — 1914-1991. São Paulo: Cia. das Letras, p. 537-562.

HURRELL, Andrew. O ressurgimento do regionalismo na política mundial. In: Contexto Internacional, vol. 17, n. 1, Rio de Janeiro, 1995.

JAGUARIBE, Helio. Problemas e perspectivas do Mercosul. In: BASSO, Maristela (Org.). Mercosul-Mercosur. Estudos em Homenagem a Fernando Henrique Cardoso. São Paulo: Atlas, 2007.

JARAMA ALVÁN, Arturo (2001). Las relaciones comerciales entre el Perú y Brasil: Importancia del eje multimodal del Amazonas para la integración binacional. Política Internacional: Revista de la Academia Diplomática del Perú, vol. 66, p. 20-45, oct./dic.

KACOWICZ, Arie M. (1999) Regionalization, globalization and nationalism: convergent, divergent, or overlaping? Alternatives, vol. 24, n. 4, p. 527-555, oct./dez.

KLUMPP, Marianne. La efectividad del sistema jurídico del MERCOSUR. Mercosul-Mercosur. Estudos em Homenagem a Fernando Henrique Cardoso. São Paulo: Atlas, 2007.

KRUGMAN, Paul R.; OBSTFELD, Maurice. Economia internacional - teoria e política. 6. ed. São Paulo: Pearson/Addison Wesley, 2005.

KUGELMAS, Eduardo. A evolução recente do FMI — crise e proposta de reforma. In: UNICAMP, CEDEC. Reestruturação econômica mundial e reformas liberalizantes nos países em desenvolvimento. Relatório parcial para a FAPESP, São Paulo, agosto 2004.

LAFER, Celso. Comércio, desarmamento, direitos humanos: reflexões sobre uma experiência diplomática. São Paulo: Paz e Terra, 1998.

LOONG, Lee Hsien. Integração em uma nova Ásia: como a ascensão da China modifica a arquitetura internacional. Cadernos Adenauer, n. 1, ano VII, 2006. Rio de Janeiro: Fundação Konrad Adenauer, 2006.

MAGNOLI, Demétrio; ARAÚJO, Regina. Projeto de ensino de geografia: natureza, tecnologias, sociedades. São Paulo: Moderna, 2002.

MARIANO, Karina L. A atuação da comissão parlamentar conjunta e do subgrupo de trabalho - 10 no Mercosul. Tese de doutorado apresentada ao Departamento de Ciência Política do Instituto de Filosofia e Ciências Humanas da Universidade de Campinas. Campinas, 2001.

MATTLI, Walter. The logic of regional integration: Europe and beyond. Cambridge: Cambridge University Press, 1999.

MAZZUOLI, Valério de Oliveira (Org.). Coletânea de direito internacional. São Paulo: Revista dos Tribunais, 2007. 
MELLO, Flavia de Campos. Política externa brasileira e os blocos internacionais. In: São Paulo em Perspectiva, São Paulo: vol. 16, n. 1, p. 44-53, jan./mar. 2002.

MENEZES, Wagner. Mercado Comum do Sul (MERCOSUL). In: MERCADANTE, Araminta de Azevedo; CELli JÚNIOR, Umberto; ARAÚJO, Leandro Rocha de (orgs.). Blocos econômicos e de integração na América Latina, África e Ásia. Curitiba: Juruá, 2008.

MERCADANTE, Araminta de Azevedo; CELLI JR., Umberto; ARAÚJO, Leandro Rocha de (Orgs.). Blocos econômicos e de integração na América Latina, África e Ásia. Curitiba: Juruá, 2008.

MERCADO JARRÍN, Edgardo (1986). Relaciones del Perú con Brasil y perspectivas dentro del espacio amazónico. In: E. Ferrero Costa (Ed.). Relaciones internacionales del Perú. Lima: CEPEI, p. 61-104.

MORACVSIK, Andrew. Preferences and power in the European Community: a liberal intergovernmentalist approach. In: BULMER, Simon; ANDREW, Scott. Economic and political integration in Europe: internal dynamics and global context. Oxford: Blackwell Publishers, 1994.

MOURA, Gerson. Brasil e Argentina: com a democracia o fim das hostilidades. In: Ciência Hoje, vol. 8 , n. 46 , set. 1988 .

MUNDO, Philip A. National politics in a global economy. The domestic sources of U. S. Trade Policy. Washington: Georgetown University Press, 1999.

OLIVEIRA, Amâncio Jorge S. N. de. O papel da coalizão empresarial brasileira e as negociações da ALCA. Tese de Doutorado apresentada no Departamento de Ciência Política da FFLCH-USP. São Paulo, 2003.

OLIVEIRA, Henrique Altemani de. Brasil-China: uma relação sul-sul. Cadernos Adenauer, n. 1, ano VII, 2006. Rio de Janeiro: Fundação Konrad Adenauer, 2006.

PEÑA, Félix. "Instituciones y concertación de intereses nacionales: algunas reflexiones en torno a la experiencia de los primeros quince años del Mercosur”. BASSO, Maristela (Org.). Mercosul-Mercosur: Estudos em Homenagem a Fernando Henrique Cardoso. São Paulo: Atlas, 2007.

PESSOA, Samuel de Abreu. Porque a economia cresce tão pouco. Conjuntura Econômica, dezembro de 2006, p. 2-15.

PUTNAM, Robert D. Diplomacy and domestic politics. The logic of two-level games. In: EVANS, Peter B.; JACOBSON, Harold K.; PUTNAM, Robert D. Double-edged diplomacy: international bargaining and domestic politics. Califórnia: University of California Press, 1993.

RIOS, Sandra Polônia; VEIGA, Pedro da Motta. O Mercosul na encruzilhada: uma agenda para os próximos anos. Grupo de Reflexão Prospectiva sobre o Mercosul. Brasília: FUNAG/ IPRI/ BID, 2003.

RIVERO, Alberto (1997). Perú y Brasil: socios amazónicos. Análisis Internacional, vol. 13, ene./dic. Lima: CEPEI, p. 32-47.

SAMANEZ BENDEZÚ, Miguel. Relaciones bilaterales Perú-Brasil. Política Internacional: Revista de la Academia Diplomática del Perú, vol. 66, oct./dic., p. 11-19, ano 2001.

SEITENFUS, Ricardo. Manual das organizações internacionais. Porto Alegre: Livraria do Advogado, 2005. SEITENFUS, Ricardo. O Mercosul e a penhora da casa. In: Estudos Avançados, vol. 19, n. 55, set./dez. 2005.

SEVERINO, Antônio Joaquim. Metodologia do trabalho científico. 20. ed. São Paulo: Cortez, 1996.

ST. JOHN, Ronald Bruce. La política exterior del Perú (Tomos I y II). Lima: Asociación de Funcionarios del Servicio Diplomático del Perú. 
SZTOMPKA, Piotr. Sociología del cambio social. Madrid: Alianza Editorial, 1995.

VELAOCHAGA, Luis. Políticas exteriores del Perú: sociología histórica y periodismo. Lima: Universidad San Martín de Porres, 2001.

VELASCO, Manuel Diez de. Las organizaciones internacionales. 11. ed. Madrid: Tecnos, 1999.

\section{Bibliografia Digital}

ACTUALIDAD ECONÓMICA DEL PERÚ. Disponível em: <http://aeperu.blogspot.com/ search/label/Comercio> Último acesso em: 20 mar. 2009.

AGÊNCIA BRASIL. Disponível em: <http://www.agenciabrasil.gov.br/noticias/2009/01/28/ materia.2009-01-28.6408761610/view> Último acesso em: 29 maio 2009.

ANUÁRIO ESTADÍSTICO DE AMÉRICA LATINA Y EL CARIBE 2005. Santiago de Chile: Comisión Económica para América Latina, 2006. Disponível em: <http://websie.eclac.ch/ anuario_estadístico/anuario_2005/esp/index.asp> Último acesso em: 15 ago. 2009.

BANCO CENTRAL DO BRASIL. Relatório Anual 2008. Brasília DF: BACEN. Disponível em: <www.bcb.gov.br> Último acesso em: 28 abr. 2009.

BANCO CENTRAL DO BRASIL (BC). Relatório Anual 2005. Brasília DF: BACEN, abril de 2006. Disponível em: <www.bcb.gov.br> Último acesso em: $1^{\circ}$ fev. 2009.

BANCO CENTRAL DE RESERVA DEL PERU. Disponível em: <www.bcrp.gob.pe/docs/ Estadisticas/Cuadros-Anuales/ACuadro_13.xls> Último acesso em: 15 jan. 2009.

BRASIL População 2008. Disponível em: <http://indexmundi.com/pt/brasil/ populacao_perfil.html> Último acesso em: 18 mar. 2009.

CARMO, Márcia. Mercosul rejeita novas regras de imigração da EU.Disponível em: <www.noticias.uol.com.br/ bbc/reporter/2008/06/30/ult4909u4303.jhtm> Último acesso em: 10 jul. 2008.

CRECIMIENTO Y PERSPECTIVA DEL COMERCIO INTERNACIONAL EN EL PERÚ 2009. Disponível em: <http://www.gestiopolis.com/economia/crecimiento-y-perspectivas-delcomercio-internacional-peru-2009.html > Último acesso em: 28 ago. 2009.

ECONOMIA APLICADA. Volume 12, n. 4, Ribeirão Preto, out./dez. 2008. Versão digital, disponível em: <http://www.scielo.br/scielo.php?pid=S141380502008000400002\&script=sci_arttext> Último acesso em: 2 jan. 2009.

GIAMBIAGI, Fabio. 18 anos de política fiscal no Brasil: 1991/2008. Economia Aplicada. Volume 12, n. 4, Ribeirão Preto, out./dez. 2008. Versão digital, disponível em: <http://www.scielo.br/ scielo.php?pid=S1413-80502008000400002\&script=sci_arttext $>$ Último acesso em: 2 jan. 2009.

IBGE Produção da Extração Vegetal e da Silvicultura 2007. Disponível em: <http:// www.ibge.gov.br/home/presidencia/noticias/noticia_impressao.php?id_noticia=1270> Último acesso em: 4 abr. 2009.

INSTITUTO BRASILEIRO DE GEOGRAFIA E ESTATÍSTICA IBGE. Disponível em: <http:// www.ibge.gov.br/home/estatistica/populacao/trabalhoerendimento/pnad2003/saude/tab19.pdf> Último acesso em: 16 mar. 2009.

MINISTÉRIO DE COMERCIO EXTERIOR Y TURISMO do Peru. Disponível em: <http:// www.mincetur.gob.pe/newweb/Portals/o/Resumen_Importaciones_2008.pdf> Último acesso em: 5 jun. 2009. 
XI Censo Nacional de Población del Instituto Nacional de Estadística del Perú. Disponível em: <http:// www1.inei.gob.pe/perucifrasHTM/inf-dem/cua1.htm> Último acesso em: 16 jan. 2009.

PERÚ BATE RECORD DE EXPORTACIÓN EN 2008. Disponível em: <http:// www.diariopyme.com/node/2087\#uno> Último acesso em: 20 mar. 2009.

PERÚ POLÍTICO. Disponível em: <http://www.perupolitico.com/?p=649> Último acesso em: 20 fev. 2009.

PIB 2007 AMÉRICA LATINA. Disponível em: <http://desarrolloperuano.blogspot.com/search/ label/PBI> Último acesso em: 7 abr. 2009.

PRO INVERSIÓN PERÚ. Disponível em: <http://www.proinversion.gob.pe/o/o/modulos/JER/ PlantillaStandardsinHijos.aspx?ARE $=0 \& P F L=0 \& J E R=1537>$ Último acesso em: 25 fev. 2009.

REPORTE MACRO ECONÓMICO. Disponível em: <http://origin.wiese.com.pe/i_financiera/ pdf/macroeconomico/20090226_mac_es.pdf> Último acesso em: 25 mar. 2009.

RIOS, Sandra; RIBEIRO, Fernando. Elementos para um programa de promoção das importações brasileiras oriundas dos países andinos. Revista Brasileira de Comércio Exterior, RBCE, ano XX, jul./set. 2006. Disponível em: <www.funcex.com.br> Último acesso em: 12 jan. 2009.

SETORES EXPORTADOR E IMPORTADOR DA ÍNDIA, Simão Davi Silber. Disponível em: <http://www.eclac.org/publicaciones/xml/6/22566/LCBRSR157Sim\%C3\%A3oDaviSilber.pdf> Último acesso em: 5 jun. 2009. 